the highlights of the tour was the visit to Olin Spidle's box plant where boxes for shipment of fish are manufactured. Each member on the tour received a one pound box used for shipping cod flakes for export to speciality shops.

Lunch consisted of traditional dishes such as pickled herring, sauer-kraut, seafood chowder and home-made rolls provided by the ladies of Mahone Bay.

In the afternoon the group visited Dafron Industries where paddles and oars are produced from clear spruce. All the shaping of paddle and oar blades is done by eye and the product finished by hand. At Myle Oxner the group was fascinated by the specially designed barrel saw which cuts 3 foot bolts into barrel staves containing the correct curvature for barrel making.

The visit to these secondary wood using industries pointed home the fact that small, free enterprise using local resources was alive and kicking in Lunenburg County.
Hollis Routledge is the new chairman of the Section, replacing Fred Cuming. New councillors are Earl Atkins, Ed Bailey, Gary Saunders and Gerry Lapointe as Secretary-Treasurer.

The new council began immediately to make preparations for the next annual meeting, to be held late this month, which will have for its theme: Education. The Education Committee, under the chairmanship of Gary Saunders is making arrangements with other resource-based groups, teachers and the Department of Education. Teachers who participated in the Forest Ecology for Teachers course will be invited to participate.

\section{G. D. van Raalte}

\section{Working Group I - Forest Surveys and Inventory}

This group has a current mailing list of 119 and is under the start-up chairmanship of J. J. Lowe, 9832 - 167 Street, Edmonton, Alberta, T5P 3V9.
One newsletter has been mailed suggesting activities and soliciting ideas.

Initial emphasis is being placed on tackling the two dragons of communication and metrication. Metrication will be on the agenda of the Niagara Falls meeting in cooperation with the Mensuration Technical Committee.

The first meeting of the working group was held south of the border! Six members of Working Group 1, plus Mike Cunia, Chairman of Working Group 3, were attending an advanced forest sampling course and took the chance to hold a luncheon meeting.

Several members of the group also attended the Inventory Design and Analysis Workshop of the SAF's Inventory Working Group. This was their first major activity, was well attended and was very good. They also are trying to reach a clear idea of what that working group should be doing - their discussions were helpful to us on the same quest.

\title{
Take a Student to Lunch
}

The Academic year has begun again and we are entering the period with 85 Student Members. At this time last year we had 173 . The change occurred when a number of our Student Members graduated and automatically became Active Members. It is encouraging, and a healthy situation, to have these young people join us.

Young blood is necessary for any viable community. They bring with them bright minds, new enthusiasm, challenging ideas and ofter a new approach which may prove to be just what is needed to help solve some of the old problems. Also they have not yet developed the apathy which sometimes develops with the years. Help them, encourage them, and take full advantage of what they have to offer.
The graduates have arrived and are among us. But the group that often needs our encouragement and help even more than these are the undergraduates. Admittedly they can, do, and should rely on their professors. But how about the opportunity to rub shoulders with the practitioner, the man in the field, the administrator?

By inviting and welcoming students to our meetings we offer them a view of the future, a chance to discuss the work of those with experience, a forum to exchange and expand their ideas. These people are the future of the $\mathrm{CIF}$ and of the profession itself. Let's provide encouragement and assistance wherever and whenever possible.

Take a student to lunch? Why not?
Do you have problems with wireworms in your nursery? The problem is easily solved according to Robbie (Teach yourself forestry. Tinling \& Co., Ltd. London. 1955): Rhubarb sticks just buried underground about two inches have proved very effective in attracting wireworms, and the wireworms can then be hand picked and destroyed. This should be done daily. The rhubarb should be re- newed weekly. / Participation filler by Brian Myers In 1971, there were estimated to be about thirty two and a quarter million street trees in the towns and cities of the United States. That's about two billion cubic feet of wood fibre on the stump, or about two hundred and twenty million thankful Americans. / Participation filler by Mike Allen 